\title{
Scholarship and the Blood Libel: Past and Present
}

Twenty years ago, I presented a paper entitled "From Crusades to Blood Libels to Expulsions: Some New Approaches to Medieval Antisemitism." ${ }^{1}$ Part of that essay attempted to assess significant recent scholarship on the blood libel by distinguished medievalists, notably Gavin Langmuir and Israel Yuval. Here I would like to expand that discussion in multiple ways: by examining how earlier scholars attempted to refute the libel, by discussing scholarship published after 1997, by assessing scholarly efforts to reveal and analyze genuinely problematic Jewish attitudes and behavior despite the danger of providing aid and comfort to antisemites, and by wrestling with the challenges of scholarly confrontation with contemporary falsehoods that Jews reflexively and often properly see as new blood libels.

\section{Medieval and Early Modern Times}

One of the earliest Jewish denunciations of the libel focuses on two themes that took center stage through the centuries: the prohibition of murder and the prohibition of consuming blood. The anonymous author of the late thirteenth-century anti-Christian polemic The Nizzahon Vetus writes that "no nation was so thoroughly warned against murder as we." He proceeds to point out that the term "your neighbor" appears in the commandment not to covet but not in "do not murder," “do not commit adultery," and "do not steal." Those prohibitions consequently apply with respect to Jews and gentiles alike. "Moreover," he continues, "we were also warned against blood more than any nation, for even dealing with meat that was slaughtered properly and is kosher, we salt it and

1 D. Berger, From Crusades to Blood Libels to Expulsions: Some New Approaches to Medieval Antisemitism, The Second Victor J. Selmanowitz Memorial Lecture (New York: Touro College Graduate School of Jewish Studies, 1997). Reprinted in D. Berger, Persecution, Polemic, and Dialogue: Essays in Jewish-Christian Relations (Boston: Academic Studies Press, 2011), 15-39.

2 OpenAccess. (C) 2020 David Berger, published by De Gruyter. (cc) BY-NC-ND This work is licensed under the Creative Commons Attribution-NonCommercial-NoDerivatives 4.0 License. 
rinse it extensively in order to remove the blood. The fact is that you are concocting allegations against us in order to permit our murder."2

On a technical level, these arguments were not without their complexities, but in the deepest sense they were entirely valid. Thus, some Jewish authorities took the position that the ten commandments were technically limited to actions within the Jewish collective, but any murder remained unambiguously forbidden by rabbinic law. As to blood, the biblical prohibition applied according to the rabbinic understanding specifically to animal blood, and so the a fortiori argument implied here is in the narrow sense incorrect. What is correct is that on an emotional, psychic level, the sense of revulsion toward blood triggered by the prohibition in question and reinforced by rabbinic law certainly led to undifferentiated abhorrence.

That a fortiori argument already appears in Frederick II's Golden Bull of 1236, which emerged out of the first formal investigation of the blood accusation. $^{3}$ The most detailed formal exoneration of the Jews by a Church official was authored by Cardinal Lorenzo Ganganelli (later Pope Clement XIV) in $1759,{ }^{4}$ though it is a matter of considerable significance that he accepted the validity of two accusations, one of which was the purported ritual murder of Simon of Trent. He argued against generalizing from these cases, but the usefulness of his report was significantly weakened by this concession since even when some defenders of the Jews conceded that one could not rule out the theoretical possibility that a deranged Jew might have killed a Christian ritually, perhaps under the influence of the libel itself, the concession was generally limited to the behavior of an individual. In the case of Trent, the allegation applied to an entire (albeit small) Jewish community, and the judicial record underlying the conviction speaks of a carefully thought-out ritual connected to the observance of Passover. To assert the validity of this accusation is to affirm that some Jewish collectives believed that their religion requires or at least looks with favor on the ritual

2 D. Berger, The Jewish-Christian Debate in the High Middle Ages: A Critical Edition of the Nizzahon Vetus with an Introduction, Translation, and Commentary (Philadelphia: Jewish Publication Society of America, 1979), English section, 229.

3 See H. L. Strack, The Jew and Human Sacrifice: Human Blood and Jewish Ritual (London: Cope \& Fenwick, 1909), 240 - 41, for an English translation of the relevant section. A footnote to p. 241 provides the Latin text of the key sentences. The sources in the last two notes were cited in A. Ehrman, "The Origins of the Ritual Murder Accusation and Blood Libel," Tradition: A Journal of Orthodox Jewish Thought 15 (1976): 87.

4 The Ritual Murder Libel and the Jew: The Report by Cardinal Lorenzo Ganganelli (Pope Clement XIV), ed. C. Roth (London: Woburn, 1935). 
murder of Christians and the consumption of their blood. The door was left open to the perpetuation of the libel.

\section{The Nineteenth and Early Twentieth Centuries}

The libel was relatively quiescent in the sixteenth, seventeenth, and eighteenth centuries-though only relatively-and then it enjoyed a resurgence beginning with the Damascus Affair of 1840 and continuing through the Beilis case in the second decade of the twentieth century. ${ }^{5}$ Needless to say, it was then reaffirmed in Nazi publications. Though efforts to refute it emerged throughout the history of the accusation, scholarly efforts to confront it intensified along with the accusation itself.

The most significant of the various scholarly responses included: Efes Damim (No Blood) by the prominent maskil Isaac Baer Levinsohn, written before the Damascus Affair, which was translated from the original Hebrew into English in the context of the Damascus libel; ${ }^{6}$ a work by Daniel Chwolson, a learned convert to Christianity who was probably the Jews' favorite apostate in all of Jewish history; ${ }^{7}$ and the most impressive and popular of them all, Hermann Strack's The Jew and Human Sacrifice. ${ }^{8}$ Strack proffered standard arguments about the prohibition of murder and blood but contributed some new or at least atypical points. He cleverly pointed to the prohibition in Jewish law against deriving benefit from a dead body and noted the requirement that a Jew of priestly lineage avoid contact with the dead. ${ }^{9}$ In another original argument, he maintained that since Jews are prepared to give up their lives for their religion, they would still be using blood annually if there were such a requirement, and

5 On Damascus, see J. Frankel, The Damascus Affair: "Ritual Murder," Politics and the Jews in 1840 (Cambridge: Cambridge University Press, 1997). On Beilis, see R. Weinberg, Blood Libel in Late Imperial Russia: The Ritual Murder Trial of Mendel Beilis (Bloomington: Indiana University Press, 2014).

6 Original Hebrew, Vilna, 1837. English translation: Ephes Dammim, trans. L. Loewe (London, 1841).

7 The Russian work appeared in 1861, and an expanded edition was issued in 1880. For the German version, see D. Chwolson, Die Blutanklage und sonstige mittelalterliche Beschuldigungen der Juden: Eine historische Untersuchung nach den Quellen (Frankfurt: J. Kauffmann, 1901).

8 The works of Levinsohn and Strack were examined briefly but insightfully by D. Biale, Blood and Belief: The Circulation of a Symbol between Jews and Christians (Berkeley: University of California Press, 2008), 164-67, $170-73$.

9 Strack, The Jew and Human Sacrifice, 129-31. 
there is no evidence of this in the "law-governed states of Europe."10 This, however, required the reader inclined to believe the accusation to accept the proposition that a country like Hungary was not law-governed. Finally, Strack provided extensive and powerful evidence that Jewish converts to Christianity rejected the accusation. $^{11}$

At this juncture, the libel was often part of a larger attack against rabbinic Judaism, and medieval assaults on the Talmud going back to Nicholas Donin in the Paris disputation of 1240 were resurrected, refurbished, and expanded. Consequently, refutations of the blood accusation became part of a broader tapestry addressing Jewish attitudes toward non-Jews in general and Christians in particular. The most notorious critic of the Talmud who also promulgated the blood libel was August Rohling, who held academic positions of some stature. ${ }^{12}$ The distinguished scholar Franz Delitzsch wrote vigorous refutations of Rohling's work, but the most wide-ranging responses were formulated by Joseph Bloch, who eventually published his magnum opus, Israel and the Nations. ${ }^{13}$ The title itself reflects the broad scope of this learned, impressive work of apologetics, which is simultaneously persuasive and problematic.

To take a central example illustrating both the challenge and the perceived need to resort to a less than wholly candid response, Bloch cites Rohling's assertion that "we (Christians) are not looked upon as idolaters as regards the doctrine of the trinity, but because we worship Jesus as God-man." ${ }^{14}$ Idolatry is not really an appropriate term, but if we substitute the Hebrew term avodah zarah, which literally means foreign worship while bearing much of the force of "idolatry," this classification of Christianity is in my view an accurate depiction of the view of almost all medieval Jewish authorities and many modern ones. The only appropriate reservation is that many of them did focus on the trinity in affirming that Christianity constitutes avodah zarah. Bloch assembled a list of quotations from medieval and modern rabbinic figures affirming that nonJews are not forbidden to associate the true God with "another being," and he dealt with the worship of Jesus as a God-man by the questionable strategy of equating it with an anthropomorphic conception of God and emphasizing that the medieval Talmudist R. Abraham b. David of Posquieres had declared such a conception non-heretical. At one point, Bloch affirmed that Maimonides him-

10 Strack, The Jew and Human Sacrifice, 153.

11 Ibid., 239-50.

12 His major work on this subject was A. Rohling, Der Talmudjude (Muenster: A. Russell, 1872).

13 J. S. Bloch, Israel and the Nations (Vienna: Harz, 1927). The original German version Israel und die Voelker was published in 1922.

14 Bloch, Israel and the Nations, 44. 
self did not consider Christians to be idolaters. ${ }^{15}$ The quotations he cites are authentic, but some are subject to other interpretations. Moreover, if we substitute avodah zarah for idolatry, the assertion about Maimonides is incorrect. Finally, much material pointing in the opposite direction is intentionally overlooked.

\section{Recent and Contemporary Times}

Beginning in the 1960s, a reconsideration of the apologetic bent emerged among Jewish historians. The pioneering work in this genre was Jacob Katz's Exclusiveness and Tolerance, which I have analyzed elsewhere at length. ${ }^{16}$ Katz provided a balanced depiction of medieval and early modern rabbinic assessments of Christianity as avodah zarah and of Jewish attitudes toward Christians and Christianity more generally. Beginning in the 1990s, two Jewish historians of stature-Israel Yuval and Elliott Horowitz-took this non-apologetic approach to new lengths by uncovering and emphasizing Jewish hostility to Christians and in Yuval's case connecting this hostility to the origins of the blood libel. ${ }^{17}$ Some observers have seen this historiographical development as a manifestation of an unprecedented Jewish sense of security, connected in part to the establishment of a Jewish state, that diminished concerns of providing ammunition to antisemites. Nonetheless-especially in the first case-vigorous criticism ensued even, perhaps especially, from Israeli scholars.

Yuval did not merely provide a candid acknowledgment of medieval Jewish hostility toward Christians; this was the primary thrust of his work. He rejected the view that such hostility emerged primarily out of persecution; rather, he said, the attitudes of Ashkenazic Jews in particular were rooted in Palestinian texts or traditions that also found expression in early medieval Italy. Moreover, he attributed the persistence of such hostility well after the first crusade to an entrenched traditional attitude since, he says, these Jews did not suffer from "especially se-

15 Bloch, Israel and the Nations, 51.

16 D. Berger, "Jacob Katz on Jews and Christians in the Middle Ages," in The Pride of Jacob: Essays on Jacob Katz and his Work, ed. J. M. Harris (Cambridge: Harvard University Press, 2002), 41-63. Reprinted in D. Berger, Persecution, Polemic, and Dialogue, 51-74.

17 Yuval's initial formulation of his thesis appeared as "Ha-Naqam ve-ha-Qelalah, ha-Dam veha-Alilah," Zion 58 (1992/1993): 33-96. This was followed by a Hebrew book translated as Two Nations in your Womb: Perceptions of Jews and Christians in Late Antiquity and the Middle Ages (Berkeley: University of California Press, 2008). The relevant discussion is in chapters 3 and 4, 92-204. For Horowitz, see Reckless Rites: Purim and the Legacy of Jewish Violence (Princeton: Princeton University Press, 2006). 
vere attacks" in the two hundred years after 1096. His commitment to this position is especially striking when we consider that he illustrates this ongoing Jewish hostility by citing a remark by Ephraim of Bonn, who was reacting to the ritual murder accusation at Blois in 1171, where more than thirty Jews were burned to death. ${ }^{18}$

Yuval's central thesis, argued with erudition and panache, is that the blood libel was probably inspired by the Jews' ritualized killing of their own children during the Crusader persecutions of 1096. This is the sort of speculation that is not subject to definitive refutation. The assertion that I find most problematic is his affirmation that the killing of children by some of the martyrs, on rare occasions even after the immediate threat seemed to have passed, was seen by the Jewish chroniclers-at least in part-as an effort to arouse God's wrath against Christians, so that He would be inspired to initiate His planned eschatological campaign of vengeance. Yuval strives to be careful in his formulation, but I think that in the final analysis, this is a fair depiction of his position, which is not, in my view, supported by any genuine evidence. The chroniclers certainly called upon God to exact such vengeance, but they did not ascribe such intentions to the martyrs themselves.

Horowitz's study, like that of Yuval, aims to expose and document Jewish hostility toward Christians and Christianity. Much of the book is focused on the holiday of Purim and the wild and sometimes violent behavior that it generated. Beyond this central theme, Horowitz demonstrated that Jews really did desecrate crosses and argued that they may sometimes have even taken the opportunity to attack or defile a consecrated host. I am persuaded that instances in which Jews defiled crosses were by no means rare; on the other hand, evidence for attacks on the host is sparse, and there is not even one instance cited by Horowitz in which Jews planned to obtain a host, succeeded in doing so, and then desecrated it. He quotes me to the effect that "I have little doubt that if [...] a Jew had found himself in possession of this idolatrous object symbolizing the faith of his oppressors, it would not have fared very well in his hands." 19 I stand by this assessment, but it is worth noting that my previous line reads, "Obtaining a consecrated host was no simple matter, and there is no reason to believe that any medieval Jew bothered to take the risk."

Horowitz also addressed the historiographical record with respect to the acknowledgment or non-acknowledgment by scholars, especially Jewish scholars, of objectionable Jewish behavior, devoting special attention to the mass killing of

18 Yuval, Two Nations, 106.

19 Horowitz, Reckless Rites, 173. 
Christians by the Jews of Israel during the Persian invasion of 614 . He points to candid presentations by some historians and suppression of uncomfortable facts by others. In his introduction, he places the work in the context of contemporary events, pointing to the identification by Jews on the extreme Right of Palestinians and even of some Jews with the biblical Amalek and underscoring the horror of Baruch Goldstein's murder of worshippers in the mosque at the Cave of the Patriarchs on Purim. On occasion, he can conflate relatively innocuous behavior with far more serious offenses; thus, the elimination of crosses from scenes in a film to be shown at an International Bible Quiz for Youth in Jerusalem is more or less equated with the action of a Jew who spat at a cross during a Christian procession. ${ }^{20}$ In addressing issues with damaging potential, historiographical candor should be tempered by cautious evaluation and rhetorical restraint.

The approaches of Yuval and Horowitz, whatever criticisms they may evoke, are the product of responsible, excellent historians. In 2007, an anomalous work on the blood libel by a heretofore serious historian appeared that crossed every red line. Ariel Toaff's Italian publication Passover of Blood treated the generally torture-induced testimonies of the Jews of Trent with the utmost seriousness and entertained the possibility that some Ashkenazic Jews may have practiced blood rites that escalated into ritual murder. ${ }^{21}$ Under the severe pressure of communal, institutional, and scholarly condemnation he withdrew the volume and produced a more restrained second edition, but the initial work was eagerly embraced by Jew-haters, and an English translation remains available on the web. ${ }^{22}$

In the wake of these developments, Hannah Johnson wrote a book entitled Blood Libel: The Ritual Murder Accusation and the Limits of Jewish History, ${ }^{23}$ which attempts to place the recent historiography into a theoretical framework. I reviewed this book in Speculum and cannot revisit it here in any detail. ${ }^{24}$ She addresses the work of Gavin Langmuir, who saw the blood libel as a product of a Christian inner struggle with religious doubt and a prime example of what he called "chimerical" antisemitism. In her view, his work suffers from a "juridical," "binary" approach in which Jews bear no responsibility at all for their victimization. Yuval, she says, introduced "an ethic of implication," while Toaff went "beyond implication." I think she goes too far in rejecting the so-

20 Horowitz, Reckless Rites, 11.

21 A. Toaff, Pasque di sangue: ebrei d'Europa e omicidi rituali (Bologna: Il Mulino, 2007).

22 https://archive.org/stream/BloodPassoveredited/BloodPassoverByToaffEdited_djvu.txt.

23 H. Johnson, Blood Libel: The Ritual Murder Accusation and the Limits of Jewish History (Ann Arbor: University of Michigan Press, 2014).

24 D. Berger, review of Blood Libel: The Ritual Murder Accusation at the Limit of Jewish History, by Hannah Johnson, Speculum 89 (2014): 210-12. 
called juridical approach, and I do not find the sophisticated theoretical framework particularly edifying.

In 2015, E. M. Rose published an important study on the earliest libels that points away from theoretical discourse and even from overarching explanations. ${ }^{25}$ Rather, she subjects the accusations in Norwich, Bury St. Edmonds, Blois, and Paris to a meticulous examination, stressing local issues of a personal, political, or economic character. The message of the book is that these early accusations should be understood in their concrete, limited context and not be "explained" by approaches that are inspired by the overall history of the libel seen through the prism of later accusations. She does not, of course, deny that even the early cases following Norwich were rooted to some degree in the earlier incidents, but she makes an explicit point of avoiding the term antisemitism or any equivalent formulation. The book indeed calls into question the persuasiveness of efforts to explain the origins of the libel through factors that transcend local motivations, but the thorough rejection of any generalized reference to hostility toward Jews seems excessive.

In a very different vein, Rose sometimes assigns too powerful a historical role to the libels that she examines. Thus, she says that the burning of the Jews of Blois

constituted a radical reinterpretation of the status of Jews in Christian society, for it contradicted traditional views of Judaism as a divinely ordained stage in the evolution of sacred history [...] The condemnation of Jews at Blois overturned the notion of toleration, replacing it with a determination that for their perfidy, Jews could be rooted out and killed. ${ }^{26}$

This, I think, is an extreme overstatement. Jews continued to be tolerated after Blois. Even the more sophisticated effort by Nicholas Donin that Jeremy Cohen sees as a delegitimation of Jewish toleration did not, in my view, succeed in overturning the fundamental doctrine. ${ }^{27}$ And the libel itself, as we have seen, was generally rejected by the Church despite the disturbing recognition and even canonization of purported victims.

25 E. M. Rose, The Murder of William of Norwich: The Origins of the Blood Libel in Medieval Europe (Oxford: Oxford University Press, 2015).

26 Rose, The Murder of William of Norwich, 237.

27 This is a central thesis of Cohen's The Friars and the Jews: The Evolution of Medieval Anti-Judaism (Ithaca: Cornell University Press, 1982). 


\section{Persistence and Transmutation of the Libel}

At the current historical juncture, the relevance of the blood libel transcends the renewed historiographical interest that we have been examining. First, the libel itself persists in the statements and writings of some not entirely marginal figures in Arab countries and to a lesser degree even elsewhere. ${ }^{28}$

Second, it has become such a paradigmatic specter for Jews that some accusations leveled at Israel are reflexively characterized as blood libels. When Menachem Begin resorted to this term to characterize international criticism of Israel for the killings in Sabra and Shatila, he was, in my view, using the term inappropriately. ${ }^{29}$ But Israel-and sometimes the Jewish collective-has in fact been subjected to imaginary accusations for which the blood libel metaphor is entirely on point. Thus, Israel poisons Palestinians; it harvests their organs; Jews, thousands of whom are said to have refrained from coming to work at the World Trade Center on that fateful September 11, are responsible in whole or in part for the attacks. A substantial number of academics signed a statement before and immediately after the outbreak of the first Gulf War alerting the world to the possibility that Israel would take advantage of the distraction caused by

28 For a list including twelve examples from 1986 to 2014, see https://en.wikipedia.org/wiki/ Blood_libel\#20th_century_and_beyond. The accusations continue. For example, Dr. Mustafa alLidawi, a former Hamas official, who has promulgated the standard libel associating ritual murder with Passover, affirmed in 2018 that Jews also kill children to utilize their blood in baking Purim pastries. See "Former Hamas Official: In The Past, The Jews Slaughtered Christian Children On Passover; Today They Torment And Kill Palestinians Instead,” MEMRI, Special Dispatch, no. 5295, issued May 6, 2013, https://www.memri.org/reports/former-hamas-officialpast-jews-slaughtered-christian-children-passover-today-they-torment and "Former Hamas Official In Antisemitic Article: The Jews Used The Blood Of Non-Jews To Prepare Pastry For Purim,” MEMRI, Special Dispatch, no. 7361, issued March 1, 2018, https://www.memri.org/re ports/former-hamas-official-antisemitic-article-jews-used-blood-non-jews-prepare-pastry-purim. See also T. Balmforth, “'Ritual Killing'? Probe Into Murder Of Tsar’s Family Spotlights Old 'AntiSemitic’ Conspiracy Theory,” Radio Free Europe/Radio Liberty, November 28, 2017, https://www. rferl.org/a/tsar-nicholas-ritual-killing-jews-anti-semitism/28884466.html for a 2017 investigation suggesting that the killing of Tsar Nicholas II was a ritual murder.

29 See D. K. Shipler, "Israeli Inquiry Give Leader 'Indirect Blame' in Massacre," The New York Times, February 9, 1983, https://www.nytimes.com/1983/02/09/world/israeli-inquiry-gives-leaders-indirect-blame-massacre-calls-for-sharon-s.html. See also JTA, "Cabinet Rejects All Accusations That Israel Was Responsible for Massacre of Palestinians in Beirut," September 21, 1982, https://www.jta.org/1982/09/21/archive/cabinet-rejects-all-accusations-that-israel-was-responsible-for-massacre-of-palestinians-in-beirut. 
the fog of war to take action against the population of the West Bank "up to fullfledged ethnic cleansing." 30

Most recently, Duke University Press has published a work by Prof. Jasbir Puar of Rutgers University entitled The Right to Maim ${ }^{31}$ whose thesis has been described as a blood libel. ${ }^{32}$ Puar asserts that Israel's policy of shooting dangerous, violent demonstrators or attackers in a manner that avoids killing them if at all possible should be seen as a strategy of maiming the Palestinian population in order to create a debilitated people more easily subject to exploitation. Written in the highly sophisticated language of theoretical discourse current in certain historical and social scientific circles, it has led a significant number of academics-as we shall see-to shower the author with extravagant praise.

At the very beginning of the volume, the reader encounters a preface entitled "Hands Up, Don't Shoot," a slogan of the Black Lives Matter movement based on the alleged cry of an unarmed black man killed by a police officer. While the author, whose unequivocal identification with the movement suffuses the entire preface, does not tell us that the victim actually said this, neither does she tell us that two investigations concluded definitively that the assertion that he did is a lie. ${ }^{33}$ Thus, the attentive reader knows after twenty-four pages that this author suppresses truth in the interest of political/ideological commitments.

Here are some examples of the level of argument in this book.

For many on both sides of the occupation, it is better to "die for your country" [...] than to face a life with a body that is deemed disabled.

30 See “American Academics Join Israeli Colleagues In Warning Against Ethnic Cleansing," San Francisco Bay Area Independent Media Center, January 30, 2003, accessed December 2, 2019, https://www.indybay.org/newsitems/2003/01/30/15682691.php. The authors cite support by elements of the Israeli coalition for "transfer" of the Palestinian population and assert that several members of parliament have advocated forcible expulsion. Aside from the fact that there was nothing remotely resembling a government plan to carry out such an action, the notion that hundreds of thousands of West Bank Palestinians could have been expelled (to Jordan? to Lebanon? to the Sinai? to Syria?) during a brief period, and this would go more or less unnoticed because the fog of war would distract world attention is so risible that it allows us to borrow Langmuir's terminology. This is chimerical anti-Israelism.

31 J. Puar, The Right to Maim: Debility, Capacity, Disability (Durham: Duke University Press, 2017).

32 See R. L. Cravatts, “'The Right to Maim’: Jasbir Puar’s Pseudo-Scholarship and Blood Libels against Israel,” The Times of Israel: Blog, November 6, 2017, https://blogs.timesofisrael.com/theright-to-maim-jasbir-puars-pseudo-scholarship-and-blood-libels-against-israel.

33 See M. Y. H. Lee, “'Hands up, don't shoot' did not happen in Ferguson,” The Washington Post, March 19, 2015, https://www.washingtonpost.com/news/fact-checker/wp/2015/03/19/ hands-up-dont-shoot-did-not-happen-in-ferguson/. 
The last part of the sentence is a formulation that would not occur to anyone on either side of the conflict. Puar invents it to lay the groundwork for the continuation, to wit,

"Not killing" Palestinians while rendering them systematically and utterly debilitated is not humanitarian sparing of death. It is instead a biopolitical usage and articulation of the right to maim. ${ }^{34}$

Even Puar cannot easily depict the roof knocks and phone calls intended to warn civilians before bombings in Gaza as part of a campaign to maim, but she is undaunted. Such measures provided very short notice, they were useless for residents who are not mobile, and in the case of phone calls, they appear more like a reminder of how powerless the Gazans are given the control that Israel has over the telecommunication networks. ${ }^{35}$ These arguments do not even begin to address the undeniable reality that these tactics constituted efforts to avoid civilian deaths (and maiming), and they underscore the lengths to which Puar will go in pursuing her imaginary thesis.

Similarly, she presents Israeli attacks on Palestinian medical facilities, ambulances, and health workers as part of an intentional policy to debilitate. ${ }^{36}$ There is not even a gesture toward finding a member of the IDF who indicates awareness of a policy of deliberate targeting of medical infrastructure and services because they treat the ill, disabled, and wounded. Since some Israeli soldiers have made vigorous, public assertions of unethical behavior by members of the IDF, and it is virtually impossible that this purported policy could have been kept secret from every soldier and officer with such inclinations, the absence of such a reference speaks volumes.

Building on a hyperbolic statement by a Gazan Water Utilities official that it would be better if Israel would just drop a nuclear bomb on Gaza, she asserts with evident agreement that he is essentially saying that "it is as if withholding death-will not let or make die-becomes an act of dehumanization: the Palestinians are not even human enough for death." 37

It is by no means improper to classify this book as the rough equivalent of the blood libel. Moreover, its publication points to an even deeper concern, namely, the corruption of the academy. During the Beilis trial of 1913, the prosecution was hard pressed to find an academic who would testify that the blood

34 Puar, The Right to Maim, 108.

35 Ibid., 129.

36 Ibid., $133-34$.

37 Ibid., $140-41$. 
accusation is true, and it had to mobilize a priest from Tashkent who was easily, if cleverly, discredited under cross-examination. The Right to Maim was not only published by a respected university press; it also bears an effusive blurb from the prominent academic Judith Butler, and when a talk that Puar delivered at Vassar College on this theme was attacked in a Wall Street Journal article, nearly one thousand academics ranging from distinguished professors like Rashid Khalidi to graduate students-most of whom have no expertise in relevant fieldswrote a letter to the president of the university containing a similarly effusive declaration of the quality of her work and her standing as a scholar. Most recently, the National Women's Studies Association announced that Puar's book is the co-winner of their Alison Piepmeier Book Prize for 2018 awarded for contributions to feminist disability studies.

Even amidst the moral and intellectual wreckage that litters the academic landscape with respect to Israel, this award stands out. Thus, my instinct that a book like this, for all its footnotes and hyper-sophisticated jargon, should be ignored because of its manifest absurdity, is, I am afraid, misguided. Academics who care about Jews and Israel, and even those who care only about the academy itself, face a daunting challenge. ${ }^{38}$

\section{Conclusion}

The survival of the blood libel through the centuries has, I think, engendered not only fear, anger, and depression but also a degree of puzzlement. In a famous essay, the nineteenth-century Hebrew writer who called himself Ahad ha-Am affirmed that the revival of the libel can serve as a "partial consolation" by preventing Jews from internalizing anti-Jewish stereotypes and accusations on the assumption that people would not conjure up characterizations of Jews and their behavior that did not have some element of truth. Since every Jew, he wrote, recognizes the utter falsity of this accusation, its persistence serves to counter this damaging threat to the Jewish self-image.

The primary imperative, however, was to refute the libel, and we have seen how this objective was pursued by polemicists and scholars, aided on occasion

38 After the presentation of this paper and the subsequent publication of a slightly modified version of its final section (D. Berger, "Academic Prize for Scholarly Form of Blood Libel," The Jewish Week, September 27, 2018, https://jewishweek.timesofisrael.com/academic-prizefor-scholarly-form-of-blood-libel/), C. Nelson's important work Israel Denial: Anti-Zionism, AntiSemitism, and the Faculty Campaign against Israel (Bloomington: Indiana University Press, 2019) appeared with a detailed, devastating analysis (202-57) of Puar's work. 
by the testimony of Christian converts. To a significant degree, the power and persuasiveness of this effort succeeded in marginalizing the accusation, though by no means wiping it out. In a world where the threat appeared to have abated, some scholars felt comfortable to point to Jewish beliefs and behavior that in their view contributed to this lie.

We now face a situation in which falsehoods no less egregious than the blood libel are leveled against the only Jewish state. Some of the purveyors of these falsehoods are no less committed to them than the medieval and early modern executioners and torturers were to the validity of the libel, and there is no hope of persuading them otherwise. But a substantial segment of the audience susceptible to their assertions is not impervious to evidence and reasoned argument, and the largely successful polemic against the blood libel itself pursued by scholars of previous generations can serve as a precedent for contemporary efforts to overcome the resurgence of chimerical and near-chimerical fantasies about Jews and the Jewish state.

David Berger is Ruth and I. Lewis Gordon Distinguished Professor of Jewish History at the Bernard Revel Graduate School of Jewish Studies at Yeshiva University. A former President of the Association for Jewish Studies, he is the author of the JewishChristian Debate in the High Middle Ages; Persecution, Polemic, and Dialogue: Essays in Jewish-Christian Relations, and Cultures in Collision and Conversation: Essays in the Intellectual History of the Jews.

\section{Bibliography}

Berger, David. “Academic Prize for Scholarly Form of Blood Libel.” The Jewish Week, September 27, 2018. https://jewishweek.timesofisrael.com/academic-prize-for-scholarlyform-of-blood-libel/.

Berger, David. Review of Blood Libel: The Ritual Murder Accusation at the Limit of Jewish History, by Hannah Johnson. Speculum 89 (2014): 210-12.

Berger, David. From Crusades to Blood Libels to Expulsions: Some New Approaches to Medieval Antisemitism. Volume 2 of The Second Victor J. Selmanowitz Memorial Lecture. New York: Touro College Graduate School of Jewish Studies, 1997. Reprinted in Berger, David. Persecution, Polemic, and Dialogue: Essays in Jewish-Christian Relations, 15-39. Boston: Academic Studies Press, 2011.

Berger, David. "Jacob Katz on Jews and Christians in the Middle Ages." In The Pride of Jacob: Essays on Jacob Katz and his Work, edited by Jay M. Harris, 41-63. Cambridge: Harvard University Press, 2002. Reprinted in Berger, David. Persecution, Polemic, and Dialogue: Essays in Jewish-Christian Relations, 51-74. Boston: Academic Studies Press, 2011. 
Berger, David. The Jewish-Christian Debate in the High Middle Ages: A Critical Edition of the Nizzahon Vetus with an Introduction, Translation, and Commentary. Philadelphia: Jewish Publication Society of America, 1979.

Biale, David. Blood and Belief: The Circulation of a Symbol between Jews and Christians. Berkeley: University of California Press, 2008.

Bloch, Joseph Samuel. Israel and the Nations. Vienna: Harz, 1927.

Cohen, Jeremy. The Friars and the Jews: The Evolution of Medieval Anti-Judaism. Ithaca: Cornell University Press, 1982.

Chwolson, Daniel A. Die Blutanklage und sonstige mittelalterliche Beschuldigungen der Juden: Eine historische Untersuchung nach den Quellen. Frankfurt: J. Kauffmann, 1901.

Cravatts, Richard L. “'The Right to Maim': Jasbir Puar's Pseudo-Scholarship and Blood Libels against Israel." The Times of Israel: Blog. November 6, 2017. https://blogs.timesofisrael. com/the-right-to-maim-jasbir-puars-pseudo-scholarship-and-blood-libels-against-israel.

Ehrman, Albert. "The Origins of the Ritual Murder Accusation and Blood Libel." Tradition: $A$ Journal of Orthodox Jewish Thought 15 (1976): 83-90.

Frankel, Jonathan. The Damascus Affair: "Ritual Murder," Politics and the Jews in 1840. Cambridge: Cambridge University Press, 1997.

Horowitz, Elliott. Reckless Rites: Purim and the Legacy of Jewish Violence. Princeton: Princeton University Press, 2006.

Johnson, Hannah. Blood Libel: The Ritual Murder Accusation and the Limits of Jewish History. Ann Arbor: University of Michigan Press, 2014.

Katz, Jacob. Exclusiveness and Tolerance: Studies in Jewish-Gentile Relations in Medieval and Modern Times. New York: Behrman House, 1961.

Lee, Michelle Ye Hee. “'Hands up, don't shoot' did not happen in Ferguson.” The Washington Post, March 19, 2015. https://www.washingtonpost.com/news/fact-checker/wp/2015/03/ 19/hands-up-dont-shoot-did-not-happen-in-ferguson/.

Nelson, Cary. Israel Denial: Anti-Zionism, Anti-Semitism, and the Faculty Campaign against Israel. Bloomington: Indiana University Press, 2019.

Puar, Jasbir. The Right to Maim: Debility, Capacity, Disability. Durham: Duke University Press, 2017.

Rohling, August. Der Talmudjude. Münster: A. Russell, 1872.

Rose, E. M. The Murder of William of Norwich: The Origins of the Blood Libel in Medieval Europe. Oxford: Oxford University Press, 2015.

Roth, Cecil, ed. The Ritual Murder Libel and the Jew: The Report by Cardinal Lorenzo Ganganelli (Pope Clement XIV). London: Woburn, 1935.

Shipler, David K. “Israeli inquiry Give Leader 'Indirect Blame' in Massacre." The New York Times, February 9, 1983.

https://www.nytimes.com/1983/02/09/world/israeli-inquiry-gives-leaders-indirect-blame-massacre-calls-for-sharon-s.html.

Strack, Hermann L. The Jew and Human Sacrifice: Human Blood and Jewish Ritual. London: Cope \& Fenwick, 1909.

Toaff, Ariel. Pasque di sangue: ebrei d'Europa e omicidi rituali. Bologna: II Mulino, 2007.

Yuval, Israel. "Ha-Naqam ve-ha-Qelalah, ha-Dam ve-ha-Alilah.” Zion 58 (1992/93): 33-96.

Yuval, Israel. Two Nations in your Womb: Perceptions of Jews and Christians in Late Antiquity and the Middle Ages. Berkeley: University of California Press, 2008. 
Weinberg, Robert. Blood Libel in Late Imperial Russia: The Ritual Murder Trial of Mendel Beilis. Bloomington: Indiana University Press, 2014. 
